\title{
Application of factorial design and Doehlert matrix in the optimisation of instrumental parameters for direct determination of silicon in naphtha using graphite furnace atomic absorption spectrometry
}

\author{
Joana Angélica de Azerêdo Amaro ${ }^{a, b}$ and Sérgio L. C. Ferreira ${ }^{* b}$ \\ ${ }^{a}$ Petrobras-Petroleo Brasileiro S. A., Refinaria Landulfo Alves Rodovia Ba $523 \mathrm{Km} \mathrm{4,}$ \\ São Francisco do Conde, Bahia, Brazil 43970-000. E-mail: joanaamaro@petrobras.com.br \\ ${ }^{b}$ Universidade Federal da Bahia, Instituto de Química, Grupo de Pesquisa em Química \\ Analítica, Campus Universitário de Ondina, Salvador, Bahia, Brazil 40170-290. \\ E-mail: slcf@ufba.br; Fax: 55-71-2355166
}

Received 30th September 2003, Accepted 1st December 2003

First published as an Advance Article on the web 20th January 2004

\begin{abstract}
A method for direct determination of silicon in naphtha samples using graphite furnace atomic absorption spectrometry (GFAAS) is proposed. The optimisation of the instrumental conditions was multivariate using a fractional factorial design and Doehlert matrix. Firstly, the fractional factorial design was performed for preliminary evaluation of the significance of the factors, the factors chosen being: sample volume, atomisation temperature, pyrolysis time and pyrolysis temperature. The results demonstrated that the variables sample volume, varying from 10 to $30 \mu \mathrm{L}$, and pyrolysis time, from 10 to $40 \mathrm{~s}$, were not significant. However, the variables pyrolysis temperature and atomisation temperature in the levels studied were statistically significant. Because of this, a Doehlert design was performed in order to determine the optimum conditions for pyrolysis and atomisation temperature. The response surface obtained indicated a maximum at $728{ }^{\circ} \mathrm{C}$ for the pyrolysis temperature and at $2696{ }^{\circ} \mathrm{C}$ for the atomisation temperature. The proposed method allows silicon determination in naphtha with a detection limit of $15 \mu \mathrm{g} \mathrm{L}^{-1}$ and a characteristic mass of $143 \mathrm{pg}$. The precision, expressed as relative standard deviation, was 8 and $11.4 \%$ for silicon concentrations of 100 and $50 \mu \mathrm{g} \mathrm{L}^{-1}$, respectively. Addition/recovery tests of silicon in several naphtha samples proved that this procedure could be applied satisfactorily for analysis of this matrix. The proposed method has been used for silicon determination in naphtha samples processed at Petrobras (São Francisco do Conde, Bahia, Brazil).
\end{abstract}

\section{Introduction}

Naphtha is a petroleum fraction containing $\mathrm{C}_{4}-\mathrm{C}_{15}$ hydrocarbon compounds, which is used in the petroleum industry for gasoline formulation and also by petrochemical industries for producing a wide range of chemical products. The determination of trace elements, such as vanadium, nickel, sodium, mercury, arsenic, lead, antimony, silicon and phosphorus, in naphtha is very important because these elements can cause poisoning of catalysts used during naphtha cracking in petrochemical industries and/or treatments for reducing sulfur and olefins in gasoline. ${ }^{1-3}$ Silicon can affect the catalysts of the naphtha reforming ${ }^{4}$ process, including processes such as hydrogenation ${ }^{5}$ and hydro treatment. ${ }^{6}$

Silicon is present in naphtha as polysiloxanes, which are used as antifoam products in several petroleum industry processes. In coked naphtha, silicon is present at a high concentration $\left(>1.0 \mu \mathrm{g} \mathrm{mL}^{-1}\right)$ and can easily be determined by flame atomic absorption spectrometry (FAAS) using a nitrous oxideacetylene flame. ${ }^{7}$ For cracked naphtha, however, the silicon concentration is very low and FAAS cannot be used. Graphite furnace (GF) AAS is a good alternative for the determination of trace amounts of silicon in a variety of matrices, but has not yet been described for the determination of silicon in naphtha.

Manning and Fernandez ${ }^{8}$ observed that a higher analytical signal could be obtained for silicon in the presence of nitrogen than in the presence of argon. Müller-Vogt and Wendl investigated carefully the determination of silicon using GFAAS. ${ }^{9}$ They studied the reactions of sodium silicate in the graphite tube, and observed that the reduction to $\mathrm{SiO}_{(\mathrm{s})}$ and $\mathrm{Si}_{(\mathrm{s})}$ started above $1200{ }^{\circ} \mathrm{C}$, and the formation of $\mathrm{SiC}_{(\mathrm{s})}$ above
$1700{ }^{\circ} \mathrm{C}$. The same authors also reported that the pyrolysis time had a marked influence on the sensitivity of the silicon determination for pyrolysis temperatures below $1550{ }^{\circ} \mathrm{C}$. Shoukry and co-workers ${ }^{10}$ stated that the main problem in the silicon determination by GFAAS is the formation of thermally stable silicon carbide and also of volatile SiO. They observed a decrease in sensitivity for silicon determination using a pyrolysis temperature of $1250{ }^{\circ} \mathrm{C}$. Brown and co-workers also reported the problem of silicon carbide ${ }^{11}$ formation. Several papers have been published about the use of modifiers to avoid reactions of the analyte with graphite, such as a determination of silicon in serum using a mixture of palladium and rhodium salts as chemical modifier, ${ }^{12}$ or in urine and blood using nickel chloride. ${ }^{13}$ Recently, methods for silicon determination in milk $^{14}$ and titanium pieces ${ }^{15}$ were proposed using palladium and palladium-magnesium, respectively, as chemical modifiers.

Multivariate techniques have been widely applied in the optimisation of methods in analytical chemistry. ${ }^{16-23}$ However, in the optimisation of instrumental conditions for metal determinations using GFAAS these techniques have not been so widespread. Araujo et al. $^{24}$ applied factorial design for optimisation of the instrumental variables in the determination of cadmium by GFAAS. Benzo et al. ${ }^{25}$ used factorial designs and response surface methodology for investigation of the most important variables and their interaction in the atomisation of vanadium. Campos et al. ${ }^{26}$ determined the optimum conditions for the use of iridium as the permanent modifier for lead determination in whole blood and urine also using two-level factorial design. Arruda et al. ${ }^{27}$ used the same principle for optimisation of the pyrolysis and atomisation temperatures for 
the determination of cadmium, aluminium, molybdenum and lead using several permanent modifiers. Instrumental variables $^{28}$ for antimony determination by GFAAS were optimised using simplex design. The determination of cadmium, manganese and copper in sea-water was optimised using experimental design, ${ }^{29}$ and Doehlert design was used for the interpretation of atomisation interferences in the determination of molybdenum by GFAAS. ${ }^{30}$

Full factorial design ${ }^{31,32}$ is one of the most frequently applied chemometric techniques in multivariate optimisation. It has been used for preliminary evaluation of the significance of variables. The number of experiments required for it is calculated as $(N)=2^{k}$, where $(k)$ is the number of variables. If the number of variables is large, the fractional factorial design can be more indicative.

Doehlert matrix ${ }^{33}$ describes a spherical experimental domain and it stresses uniformity in space filling. For two variables it consists of one central point and six points forming a hexagon, situated on a circle. ${ }^{34}$ The formula used for calculation of the number $(N)$ of experiments required is $\left(N=k^{2}+k+C_{0}\right)$, where $(k)$ is the number of variables and $\left(C_{0}\right)$ is the number of center points. ${ }^{32}$ Replicates at the central level of the variables are performed in order to validate the model by means of an estimate of experimental variance. This way, each design is defined considering the number of variables and the coded values $\left(C_{i}\right)$ of the established matrix. The relationship between coded and real values is given by:

$$
C_{i}=\left\{\left(X_{i}-X_{i}^{0}\right) /\left(\Delta X_{i}\right)\right\} \times \alpha
$$

where $\left(C_{i}\right)$ is the coded value for factor $i,\left(X_{i}\right)$ is the real value in an experiment, $\left(X_{i}^{0}\right)$ is the real value at the center of experimental domain, $\left(\Delta X_{i}\right)$ the step of variation of the real value and $(\alpha)$ is the limit of the coded value for each factor.

In our research group, Doehlert matrix has been used for optimisation of a preconcentration procedure for determination of molybdenum ${ }^{35}$ and vanadium ${ }^{36}$ in sea-water samples by ICPOES, of on-line preconcentration systems for the determination of lead ${ }^{37}$ and zinc $^{38}$ by FAAS and, more recently, in the optimisation of instrumental conditions for arsenic determination in naphtha using GFAAS. ${ }^{39}$

In the present paper, a procedure has been developed for the determination of trace amounts of silicon in naphtha samples using GFAAS. The instrumental conditions were optimised using fractional factorial design and Doehlert matrix.

\section{Experimental}

\section{Apparatus}

All experiments were carried out in an electrothermal atomic absorption spectrometer with Zeeman-effect background correction (Varian, Model Spectra AA220Z), equipped with an autosampler (Varian, Model PSD 100) and connected to a PC. Pyrolytic graphite coated graphite tubes were used. Nitrogen $99.996 \%$ (White Martins, Brazil) was used as the purge gas. The hollow cathode lamp (silicon UltrAA lamp, Varian) was operated at $251.6 \mathrm{~nm}$ with $20 \mathrm{~mA}$ current and a spectral bandwidth of $0.2 \mathrm{~nm}$.

\section{Reagents and solutions}

Silicon base oil standard of $5000 \mathrm{mg} \mathrm{kg}^{-1}$ was supplied by Conostan (Conostan Oil Analysis Standards, Ponca City, OK, USA).

Silicon stock standard solution of $50 \mathrm{mg} \mathrm{L}^{-1}$ was prepared using toluene (Merck, Darmstadt, Germany) as solvent. All working standard solutions were prepared daily from this standard using kerosene (Petrobras, Bahia, Brazil) as the solvent.

\section{Samples}

All naphtha samples were collected in new and cleaned polyethylene bottles and stored in a freezer at $4{ }^{\circ} \mathrm{C}$ prior to analysis. The samples were collected from the raw material storage tank or directly from the ship. Typical physical properties of naphtha were distillation curve usually ranging from $40{ }^{\circ} \mathrm{C}$ to $220{ }^{\circ} \mathrm{C}$ and specific gravity around $0.73 \mathrm{~kg} \mathrm{~L}^{-1}$.

\section{Optimisation strategy}

The optimisation process was carried out using a fractional factorial design and Doehlert matrix involving two variables. The experiments were carried out in random order. Four variables (sample volume, atomisation temperature, pyrolysis time and pyrolysis temperature) were regarded as factors. The factorial design was evaluated by using the normalised "absorbance" as response, because of the volume variation during this experiment. The analytical signal (absorbance) can be measured using peak area or peak height method. In this paper was used the peak height because the obtained peak is sharp and well defined. The evaluation of the results of the factorial design was carried using the analysis of variance at 95\% confidence level and the Pareto Chart. In these charts, the bar lengths are proportional to the absolute value of the estimated effects, helping in comparing the relative importance of the effects. The signal positive or negative allows also another interpretation of the effects. This chart is obtained using a statistical program. The experimental data were processed using the STATISTICA computer program. ${ }^{40}$

\section{Results and discussion}

\section{Optimisation of the instrumental conditions}

The optimisation process was performed in two steps. Firstly, a fractional factorial design $2^{4-1}$ was carried out, involving the variables: sample volume, atomisation temperature, pyrolysis time and pyrolysis temperature. The experimental conditions of drying time, drying temperature, gas flow and clean step were fixed as recommended by the spectrometer manufacturer, and are described in Table 1. The drying temperature also was not considered as a variable in the optimisation process and it was found from the range of distillation temperature of naphtha $\left(40-220^{\circ} \mathrm{C}\right)$. In the experimental design the variation of sample volume was established by considering results of previous experiments. The atomisation temperature, pyrolysis time and pyrolysis temperature were changed as recommended by the spectrometer manufacturer. The levels, minimum and maximum, of these factors are described in Table 2. The analytical response used for evaluation of the factorial design was the normalised absorbance because of the volume variation during this experiment. The matrix of the factorial design and its results are described in Table 3. The interpretation of the results of this design was carried out considering the Pareto Chart of main effects shown in Fig. 1. The results

Table 1 Graphite furnace temperature program

\begin{tabular}{lllll}
\hline Cycle & Step & Temperature $/{ }^{\circ} \mathrm{C}$ & Time/s & Flow $/ \mathrm{L} \mathrm{min}^{-1}$ \\
\hline Drying & 1 & 40 & 1.0 & 3.0 \\
& 2 & 80 & 10.0 & 3.0 \\
& 3 & 150 & 10.0 & 3.0 \\
Pyrolysis & 4 & 250 & 30.0 & 3.0 \\
& 5 & 728 & 10.0 & 3.0 \\
& 6 & 728 & 15.0 & 3.0 \\
Atomization & 7 & 728 & 3.0 & 0.0 \\
Cleaning & 9 & 2696 & 1.0 & 0.0 \\
& 10 & 2696 & 2.0 & 0.0 \\
& & 2700 & 4.0 & 3.0
\end{tabular}


Table 2 Factors and levels used in factorial design

\begin{tabular}{lll}
\hline Variable & Low $(-)$ & High $(+)$ \\
\hline Sample volume (SV) & $10 \mu \mathrm{L}$ & $30 \mu \mathrm{L}$ \\
Atomisation temperature (AT) & $2500{ }^{\circ} \mathrm{C}$ & $2700{ }^{\circ} \mathrm{C}$ \\
Pyrolysis time (Py-t) & $10 \mathrm{~s}$ & $40 \mathrm{~s}$ \\
Pyrolysis temperature (PyT) & $700{ }^{\circ} \mathrm{C}$ & $1100{ }^{\circ} \mathrm{C}$ \\
\hline
\end{tabular}

Table 3 Matrix of the factorial design

\begin{tabular}{llllll}
\hline No & $($ vol $)$ & $($ AT $)$ & $($ Py-t $)$ & $($ PyT $)$ & Normalised signal \\
\hline 1 & + & + & + & + & 0.0459 \\
2 & + & + & - & - & 0.0909 \\
3 & + & - & + & - & 0.0612 \\
4 & + & - & - & + & 0.0189 \\
5 & - & + & + & - & 0.1004 \\
6 & - & + & - & + & 0.0474 \\
7 & - & - & + & + & 0.0286 \\
8 & - & - & - & - & 0.0654 \\
\hline
\end{tabular}

Pareto Chart of Standardized Effects; Variable: Normalized absorbance $p=, 05$

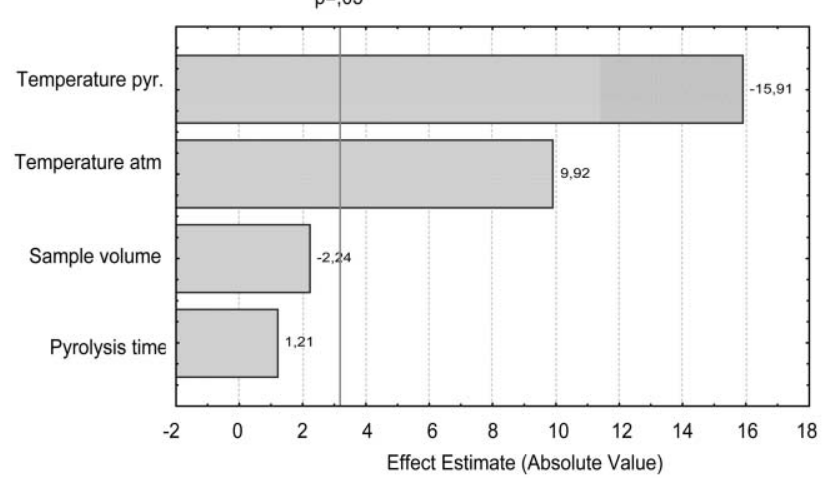

Fig. 1 Pareto chart of standardized effects; analytical response; normalized absorbance

demonstrated that the variables atomisation temperature and pyrolysis temperature are statistically significant. The negative value $(-15.91)$ for the effect of the pyrolysis temperature indicated that in the studied levels, the absorbance decreased with increase of the pyrolysis temperature. This meant that an increase of this temperature caused a loss of silicon. The positive value (9.92) for the effect of the atomisation temperature revealed that the analytical signal (absorbance) increased with increasing temperature at the studied levels. These results are obviously no surprise. The experimental design demonstrated also that the variables sample volume, varying from 10 to $30 \mu \mathrm{L}$, and pyrolysis time, varying from 10 to $40 \mathrm{~s}$, are not statistically significant.

\section{Final optimisation using a Doehlert design}

Results of the factorial design demonstrated that the variables (pyrolysis and atomisation temperature) in the studied levels required a final optimisation. Thus, a Doehlert design involving these variables was performed. The pyrolysis temperature varied from 650 to $850{ }^{\circ} \mathrm{C}$ and atomisation temperature from 2657 to $2743{ }^{\circ} \mathrm{C}$. These ranges of temperatures were established considering also the results of the factorial design. The experiments required in this step are described in Table 4. The data obtained were used in the Doehlert matrix, considering the coded values and the equation below illustrates the relation among pyrolysis temperature (PyT), atomisation temperature (AT) and analytical signal (AS). The corresponding
Table 4 Doehlert design for optimisation of the pyrolysis and atomisation temperature ${ }^{a}$

\begin{tabular}{lrrr}
\hline Experiment & $\begin{array}{l}\text { Pyrolysis } \\
\text { temperature }\end{array}$ & $\begin{array}{l}\text { Atomisation } \\
\text { temperature }\end{array}$ & Absorbance \\
\hline 1 & $1.000(850)$ & $0.000(2700)$ & 0.0540 \\
2 & $-1.000(650)$ & $0.000(2700)$ & 0.1237 \\
3 & $0.500(800)$ & $0.866(2743)$ & 0.0627 \\
4 & $-0.500(700)$ & $0.866(2743)$ & 0.1078 \\
5 & $0.500(800)$ & $-0.866(2657)$ & 0.1037 \\
6 & $-0.500(700)$ & $-0.866(2657)$ & 0.1134 \\
7 & $0.000(750)$ & $0.000(2700)$ & 0.1496 \\
8 & $0.000(750)$ & $0.000(2700)$ & 0.1692 \\
$a$ (Real values). & & & \\
\hline
\end{tabular}

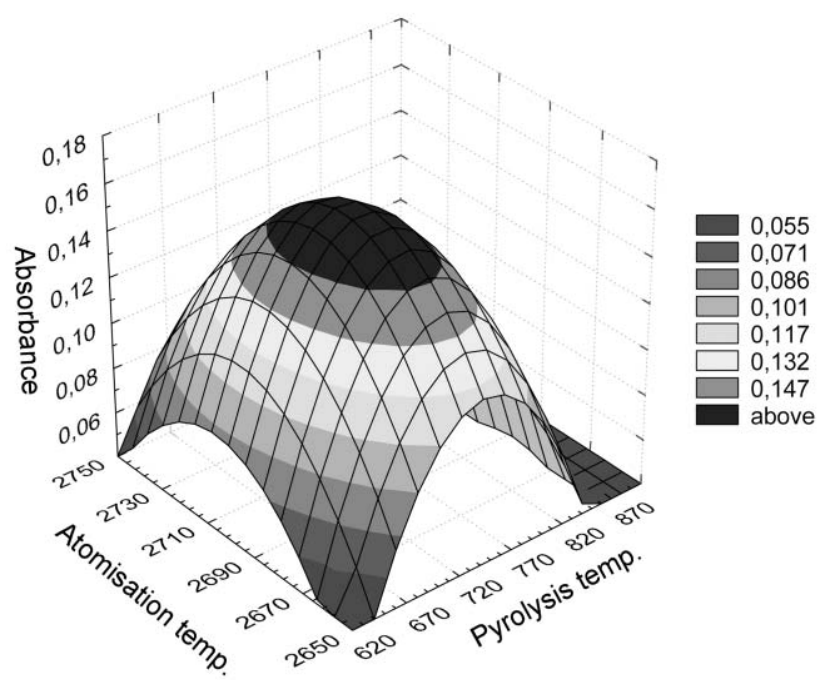

Fig. 2 Doehlert matrix for optimisation of pyrolysis and atomisation temperature.

surface response is shown in Fig. 2.

$$
\begin{gathered}
(\mathrm{AS})=0.159-0.0324(\mathrm{PyT})-0.0134(\mathrm{AT})- \\
0.0706(\mathrm{PyT})^{2}-0.0204(\mathrm{AT})(\mathrm{PyT})-0.0598(\mathrm{AT})^{2}
\end{gathered}
$$

The application of Lagrange's criterion in this equation demonstrated that:

$$
\begin{aligned}
& \delta(\mathrm{AS}) / \delta(\mathrm{PyT})=-0.0324-0.141(\mathrm{PyT})-0.0204(\mathrm{AT}) \\
& \delta(\mathrm{AS}) / \delta(\mathrm{AT})=-0.0134-0.0204(\mathrm{PyT})-0.120(\mathrm{AT})
\end{aligned}
$$

The resolution of this equation system shows a critical point in the surface response, which is a maximum for the pyrolysis temperature of $(-0.218)$ and for the atomisation temperature of $(-0.0751)$. These results as coded values indicate real values of $728{ }^{\circ} \mathrm{C}$ for the pyrolysis temperature and of $2696{ }^{\circ} \mathrm{C}$ for the atomisation temperature.

The robustness ${ }^{38}$ of an analytical method is the measure of its capacity to reproduce results when the procedure is performed under small changes in the nominal values established in the optimization step. Considering that the variables in the range studied in the Doehlert design were not significant, we can conclude that the conditions established for this paper are perfectly robust.

\section{Analytical figures of merit}

Using the established conditions in the optimisation step, the method for the determination of silicon in naphtha samples 
Table 5 Silicon determination in naphtha samples

\begin{tabular}{|c|c|c|c|}
\hline Sample & $\begin{array}{l}\text { Added } \\
\text { silicon } / \mu \mathrm{g} \mathrm{L}^{-1}\end{array}$ & $\begin{array}{l}\text { Found } \\
\text { silicon }^{a} / \mu \mathrm{g} \mathrm{L}^{-1}\end{array}$ & $\begin{array}{l}\text { Recovery } \\
(\%)\end{array}$ \\
\hline \multirow[t]{4}{*}{1} & 0 & $30 \pm 3$ & - \\
\hline & 20 & $48 \pm 5$ & 96 \\
\hline & 50 & $80 \pm 6$ & 100 \\
\hline & 100 & $127 \pm 10$ & 97 \\
\hline \multirow[t]{3}{*}{2} & 0 & $63 \pm 7$ & - \\
\hline & 50 & $108 \pm 9$ & 96 \\
\hline & 80 & $144 \pm 12$ & 101 \\
\hline \multirow[t]{3}{*}{3} & 0 & $65 \pm 7$ & - \\
\hline & 50 & $120 \pm 10$ & 105 \\
\hline & 100 & $157 \pm 13$ & 95 \\
\hline
\end{tabular}

showed a linear response from $45 \mu \mathrm{g} \mathrm{L}^{-1}$ to at least $200 \mu \mathrm{g} \mathrm{L}^{-1}$ with a correlation coefficient of 0.9997 . The precision calculated from ten consecutive measurements and defined as the coefficient of variation of solutions containing 50 and $100 \mu \mathrm{g} \mathrm{L}^{-1}$ of silicon were 11 and $8 \%$, respectively. The limit of detection (LOD), defined as the silicon concentration that gives a response equivalent to three times the standard deviation $(s)$ of the blank $(n=10)$, was found to be $15 \mu \mathrm{g} \mathrm{L} \mathrm{L}^{-1}$. The characteristics mass was $143 \mathrm{pg}$.

\section{Application}

The proposed method was applied for the direct determination of silicon in three naphtha samples using the standard calibration technique. The silicon content varied from 30 to $65 \mu \mathrm{g} \mathrm{L}^{-1}$, as shown in Table 5. The recoveries were in the range from 95 to $105 \%$ of added silicon in the samples and demonstrated the accuracy of the method. Sample 1 was also analysed by the analyte addition technique with a result of $30 \pm 2 \mu \mathrm{g} \mathrm{L}^{-1}$, demonstrating that there is no significant difference.

\section{Conclusions}

A simple method for the direct determination of silicon in naphtha has been developed using graphite furnace atomic absorption spectrometry and Zeeman-effect background correction. No modifier was used and the samples were analyzed without any pretreatment. The literature ${ }^{9,10}$ states that the formation of silicon carbide starts above $1250{ }^{\circ} \mathrm{C}$. This was compatible with the instrumental conditions established in this paper. The results of fractional factorial design were also in agreement with previous papers.

The multivariate techniques used: fractional factorial design and Doehlert matrix allowed an efficient optimization among the variables.

\section{Acknowledgements}

The authors acknowledge grants from Conselho Nacional de Desenvolvimento Científico e Tecnológico (CNPq-CTPETRO) and Coordenação de Aperfeiçoamento de Pessoal de Nível Superior (CAPES) and also Professor Bernhard Welz (UFSC, Brazil) by revision of this manuscript.

\section{References}

1 Catalytic Nafta Reforming, Science and Technology, eds. G. J. Antos, A. M. Aitani and J. M. Parrera, M. Dekker, New York, 1995.

2 T. Myrstad, Appl. Catal. A: General, 1997, 155, 87.
3 T. Myrstad, B. Seijestokken, H. Engan and E. Rytter, Appl. Catal. A: General, 2000, 192, 299.

4 M. O. G. Souza, P. Reyes and M. C. Rangel, Stud. Surf. Sci. Catal., 1999, 126, 469.

5 B. Didillon, J. Cosyns, C. Cameron, D. Uzio, P. Sarrazin and J. P. Boitiaux, Stud. Surf. Sci. Catal., 1997, 111, 447.

6 P. Zeuthen and J. Brito, Abstr. Braz. Catal. Congr., 1999.

7 B. Welz and M. Sperling, Atomic Absorption Spectrometry, Wiley-VCH, 3rd edn., 1999.

8 D. C. Manning and F. J. Fernandez, At. Absorption Newsl., 1970, 9, 65.

9 G. Muller-Vogt and W. Wendl, Anal. Chem., 1981, 53, 651

10 A. F. Shoukry, Y. M. Issa, R. A. Farghaly, M. Grasserbauer, H. Puxbaum and J. Rendi, Fresenius' J. Anal. Chem., 1998, 360, 650.

11 G. N. Brown, D. L. Styris and M. W. Hinds, J. Anal. At. Spectrom., 1995, 10, 527.

12 E. Bulska, G. Chelmecki and A. Hulanicki, Can. J. Appl. Spectrosc., 1996, 41, 5.

13 R. Kobayashi, S. Okamura, K. Yamada and M. Kudo, Anal. Sci., 1997, 13(suppl. 17).

14 P. Bermejo-Barrera, M. C. Barciela-Alonso, R. DominguezGonzalez, A. Bermejo-Barrera, J. A. C. de Juan and J. M. FragaBermudez, Anal. Bioanal. Chem., 2002, 374, 1290.

15 H. M. Dong and V. Krivan, J. Anal. At. Spectrom., 2003, 18, 367.

16 E. Martinez, R. Cela, A. M. Carro, J. C. Cobas and B. Garcia, J. Anal. At. Spectrom., 2002, 17, 1373.

17 M. C. Yebra and A. Moreno-Cid, J. Anal. At. Spectrom., 2002, 17, 1425.

18 A. Lopez-Molinero, R. Gimenez, P. Otal, A. Callizo, P. Charmorro and J. R. Castillo, J. Anal. At. Spectrom., 2002, 17, 352 .

19 A. Lopez-Molinero, A. Villareal, D. Andia, C. Velilla and J. R. Castillo, J. Anal. At. Spectrom., 2001, 16, 744.

20 M. Zougagh, A. G. de Torres and J. M. C. Pavon, Anal. Lett., 2003, 36, 1115.

21 P. Bermejo-Barrera, A. Moreda-Piñeiro, O. Muñiz-Navieiro, A. M. J. Gomez-Ferñandez and A. Bermejo-Barrera, Spectrochim. Acta, Part B, 2000, 55, 1351.

22 C. Pasquini, J. Braz. Chem. Soc., 2003, 14, 198.

23 M. Grotti, E. Magi and R. Leardi, J. Anal. At. Spectrom., 2003, 18, 274.

24 P. W. Araujo, C. V. Gomez, E. Marcano and Z. Benzo, Fresenius' J. Anal. Chem., 1995, 351, 204.

25 Z. Benzo, T. Montero, M. Quintal, A. Sierraalta and F. Ruette, J. Anal. At. Spectrom., 1996, 11, 445.

26 P. Grinberg and R. C. de Campos, Spectrochim. Acta, Part B, 2001, 56, 1831.

27 E. R. Pereira-Filho, R. J. Poppi and M. A. Z. Arruda, Quim. Nova, 2002, 25, 246.

28 I. Koch, C. F. Harrington, K. J. Reimer and W. R. Cullen, Talanta, 1997, 44, 1241.

29 H. L. Garrec, P. Giamarchi, J.-Y. Cabon and A. L. Bihan, Anal. Chim. Acta, 1998, 368, 59.

30 Z. Benzo, P. Araujo, A. Sierraalta and F. Ruette, Anal. Chem., 1993, 65, 1107.

31 G. E. P. Box, W. G. Hunter and J. S. Hunter, Statistics for Experimenters, New York, Wiley, 1978.

32 D. L. Massart, B. G. M. Vandeginste, L. M. C. Buydens, S. de Jong, P. J. Lewi and J. Smeyers-Verbeke, Handbook of Chemometrics and Qualimetrics, Part A, Elsevier, Amsterdam, 2003.

33 D. Doehlert, Appl. Stat., 1970, 19, 231.

34 J. M. Bosque-Sendra, M. Nechar, L. C. Rodriguez and M. F. M. Molina, Anal. Proc., 1995, 32, 375.

35 S. L. C. Ferreira, H. C. dos Santos, M. S. Fernandes and M. S. de Carvalho, J. Anal. At. Spectrom., 2002, 17, 115.

36 S. L. C. Ferreira, A. S. Queiroz, M. S. Fernandes and H. C. dos Santos, Spectrochim. Acta, Part B, 2002, 57, 1939.

37 S. L. C. Ferreira, W. N. L. dos Santos, M. A. Bezerra, V. A. Lemos and J. M. Bosque-Sendra, Anal. Bioanal. Chem., 2003, 375, 443.

38 W. N. L. dos Santos, C. M. N. Santos and S. L. C. Ferreira, Microchem. J., 2003, 75, 211.

39 M. V. Rebouças, S. L. C. Ferreira and B. B. Neto, J. Anal. At. Spectrom., 2003, 18, 1267.

40 Statistica for Windows, StatSoft, Inc., 2300 East 14th Street, Tulsa, OK 741014, USA, 1999. 